\title{
The Likert scale is a powerful tool for quality of life assessment among patients after minimally invasive coronary surgery
}

\author{
Łukasz J. Krzych ${ }^{1}$, Małgorzata Lach $^{2}$, Michał Joniec $^{3}$, Marek Cisowski $^{4}$, Andrzej Bochenek ${ }^{4}$ \\ ${ }^{1}$ Department of Anaesthesiology and Intensive Care, Medical University of Silesia, Katowice, Poland \\ ${ }^{2}$ Department of General Surgery with Intensive Postoperative Care Subdivision, Hospital in Myslenice, Myslenice, Poland \\ ${ }^{3}$ Department of Cardiology, Hospital in Jaworzno, Jaworzno, Poland \\ ${ }^{4}$ Department of Cardiac Surgery, American Heart of Poland, Bielsko-Biala, Poland
}

Kardiochirurgia i Torakochirurgia Polska 2018; 15 (2): 130-134

\begin{abstract}
Introduction: Health-related quality of life (QoL) is an acknowledged index of treatment effectiveness. There are several methods of its evaluation which are predisposed to different risk of bias.

Aim: To investigate the agreement between objective and subjective tools of QoL assessment in patients who underwent endoscopic atraumatic coronary artery bypass (EACAB) grafting. Material and methods: This prospective observational study covered 705 consecutive patients who underwent EACAB between April 1998 and December 2010. Quality of life was assessed in a follow-up of $2132 \pm 1313$ days among 482 subjects using the WHOQoL-BREF questionnaire as an objective tool and the Likert scale as a more subjective method.

Results: There was good agreement between a 5-step Likert scale and a 5-step BREF Q1 ('overall quality of life') and Q2 ('general health') with a concordance correlation coefficient of $C C C=0.64(95 \% \mathrm{Cl}: 0.58-0.69)$ and CCC $=0.49$ (95\% Cl: $0.43-$ $0.55)$, respectively. There was also a statistically significant correlation between answers reported using the Likert scale and all domains of BREF: physical health $(R=0.54, p<0.001)$, psychological health $(R=0.56, p<0.001)$, social relationships $(R=0.45, p<0.001)$ and environment $(R=0.56, p<0.001)$.

Conclusions: The Likert scale is useful in QoL assessment in patients after minimally invasive coronary surgery. This simple and easy-to-use screening method may be used interchangeably with a more reliable but also more complex questionnaire tool.
\end{abstract}

Key words: quality of life, WHOQoL-BREF questionnaire, Likert scale.

\section{Introduction}

Health-related quality of life (HRQoL) is usually described as the influence of the disease and its treatment on

\section{Streszczenie}

Wstęp: Ocena jakości życia (QoL) jest uznanym miernikiem efektywności terapii. Istnieją różnorodne metody analizy jakości życia uwarunkowanej aktualnym stanem zdrowia (HRQoL), które różnią się swoistością i czułością.

Cel: Porównanie obiektywnego i subiektywnego narzędzia oceny HRQoL u pacjentów, którzy przeszli endoskopowe atraumatyczne pomostowanie tętnic wieńcowych (EACAB).

Materiat i metody: Prospektywne badanie obserwacyjne obejmowało 705 kolejnych pacjentów, którzy przeszli EACAB od kwietnia 1998 do grudnia 2010 r. Jakość życia oceniono u 482 osób za pomocą kwestionariusza WHOQoL-BREF jako obiektywnego narzędzia i skali Likerta jako metody subiektywnej. Średni czas obserwacji wynosit $2132 \pm 1313$ dni.

Wyniki: Stwierdzono zadowalającą zgodność między 5-stopniową skalą Likerta a 5-stopniowymi wskazaniami kwestionariusza BREF: Q1 (ogólna jakość życia) i Q2 (ogólny stan zdrowia): współczynniki zgodności wynosity odpowiednio: CCC = 0,64 (95\% Cl: 0,58-0,69) i CCC $=0,49$ (95\% Cl: 0,43-0,55). Wykazano znamienną statystycznie korelację między odpowiedziami zgłaszanymi za pomocą skali Likerta a wszystkimi dziedzinami BREF: zdrowie fizyczne ( $R=0,54, p<0,001)$, zdrowie psychiczne $(R=0,56, p<0,001)$, relacje społeczne $(R=0,45, p<0,001)$ i środowisko $(R=0,56, p<0,001)$. Wnioski: Skala Likerta jest użyteczna w ocenie QoL u pacjentów po zabiegach małoinwazyjnego pomostowania tętnic wieńcowych. Ta prosta i łatwa w obsłudze metoda badań przesiewowych może być stosowana zamiennie z bardziej wiarygodnym, jednak złożonym narzędziem, jakim jest kwestionariusz WHOQoL-BREF.

Słowa kluczowe: jakość życia, kwestionariusz WHOQoL-BREF, skala Likerta.

the patient's social roles and a general feeling of satisfaction with life [1]. It is multifactorial and evaluates numerous aspects of everyday functioning of the patient.

Address for correspondence: Małgorzata Lach MD, PhD, Department of General Surgery with Intensive Postoperative Care Subdivision, Hospital, 2 Szpitalna St, 32-400 Myślenice, Poland, phone: +48 512027 729, e-mail: gochender@gmail.com

Received: 12.01 .2018 , accepted: 3.02 .2018 . 
The methods applied for QoL assessment should acknowledge psychometric properties and should be adjusted to the specific population and the disease. Several more or less subjective scales and questionnaires are widely used for HRQoL assessment worldwide. Subjective scales are quick and easy to use. Unfortunately, their results are prone to bias. By contrast, the questionnaires are more complex but enable us to acquire more objective information.

Quality of life has been studied predominantly among coronary patients undergoing cardiac surgery via sternotomy or those having percutaneous interventions [2-5]. Still, little is known about QoL after minimally invasive coronary artery bypass grafting via lateral thoracotomy [6-8]. Moreover, there are no convincing data regarding reliability of the available methods of QoL assessment in this unique population.

\section{Aim}

Therefore we aimed to investigate agreement between objective and subjective methods of QoL assessment among subjects who underwent endoscopic atraumatic coronary artery bypass grafting (EACAB).

\section{Material and methods}

We studied 705 consecutive patients who underwent EACAB between April 1998 and December 2010 in a highvolume tertiary cardiac surgery center in Poland. A prospective study of QoL assessment was conducted from February to December 2011. The duration of the postoperative follow-up was $2132 \pm 1313$ days (median: 1918 days). Time delay between the surgery and QoL assessment had no impact on the results of the Likert scale $(p=0.6)$ or the summary result of the WHOQOL-BREF questionnaire $(p=0.1)$ (Fig. 1). Twenty-three individuals died during this period and complete data were obtained from $68.4 \%$ of survivors.
Quality of life was assessed based on the information provided by patients by either telephone interview or letter correspondence. At the first stage, patients were asked to self-evaluate their current QoL by answering a question: 'What is your current quality of life compared to the preoperative period?' using a 5-step Likert scale [9]. The answers were reported as: considerable deterioration (level 1), deterioration (level 2), no change (level 3), improvement (level 4) or considerable improvement (level 5). At the second stage, subjects were asked to fill in a Polish version of the WHOQoLBREF questionnaire [10]. The tool consists of 26 questions describing: (1) physical health, (2) psychological health, (3) social relationships and (4) environment. To provide a broad and comprehensive assessment, one item from each of the 24 facets from the WHOQoL-100 was included. In addition, two items from the 'overall quality of life' (Q1) and 'general health' (Q2) facet were used. A detailed description of the WHO tool can be found elsewhere [10].

The study was approved by a local ethics committee. All patients provided their informed consent.

\section{Statistical analysis}

Statistical analysis was performed using MedCalc Statistical Software (MedCalc Software bvba, Ostend, Belgium). Quantitative variables are expressed as mean and standard deviation (those normally distributed) or median and interquartile range (IQR) (those non-normally distributed). The normality of distribution was verified using the Shapiro-Wilk test. Qualitative variables are expressed as crude values (percentage). Between-group differences for quantitative variables were assessed using the MannWhitney U-test. Pearson's correlation coefficient $(r)$ or Spearman's rank correlation coefficient $(R)$ was calculated for appropriate quantitative data. The concordance cor-
A

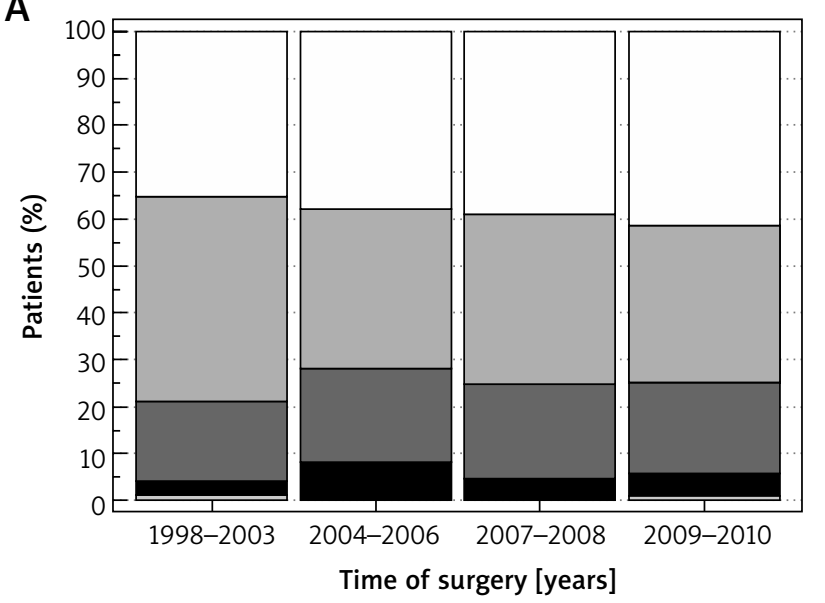

B

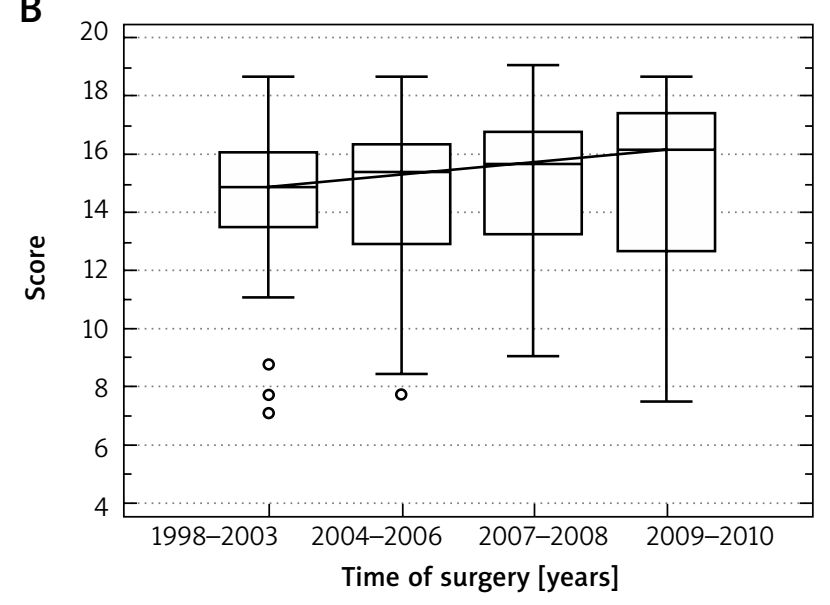

Likert scale:

$\square$ Marked deterioration $\square$ No change $\quad \square$ Marked improvement

Deterioration

$\square$ Improvement

Fig. 1. Impact of time of surgery on quality of life: A - Likert scale, B - the total score of the questionnaire 
Table I. Baseline characteristics of subjects undergoing QoL assessment

\begin{tabular}{lc} 
Variable & Value \\
Age [years] & $58 \pm 9$ \\
\hline Male gender (\%) & 81.1 \\
\hline Diabetes (\%) & 15.1 \\
\hline Body mass index $\geq 25 \mathrm{~kg} / \mathrm{m}^{2}(\%)$ & 67.9 \\
\hline Previous myocardial infarction (\%) & 38.4 \\
\hline Arterial hypertension (\%) & 44.7 \\
\hline Peripheral arterial disease (\%) & 1 \\
\hline Renal failure (\%) & 0.4 \\
\hline Obstructive pulmonary disease (\%) & 2.1 \\
\hline Left ventricle ejection fraction (\%) & $54 \pm 6$ \\
\hline
\end{tabular}

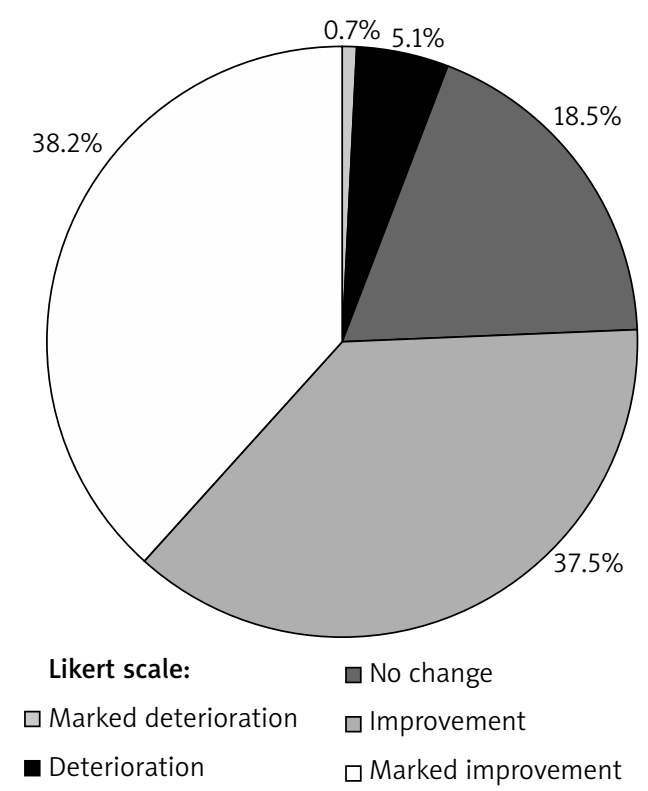

Fig. 2. Quality of life on Likert scale

A

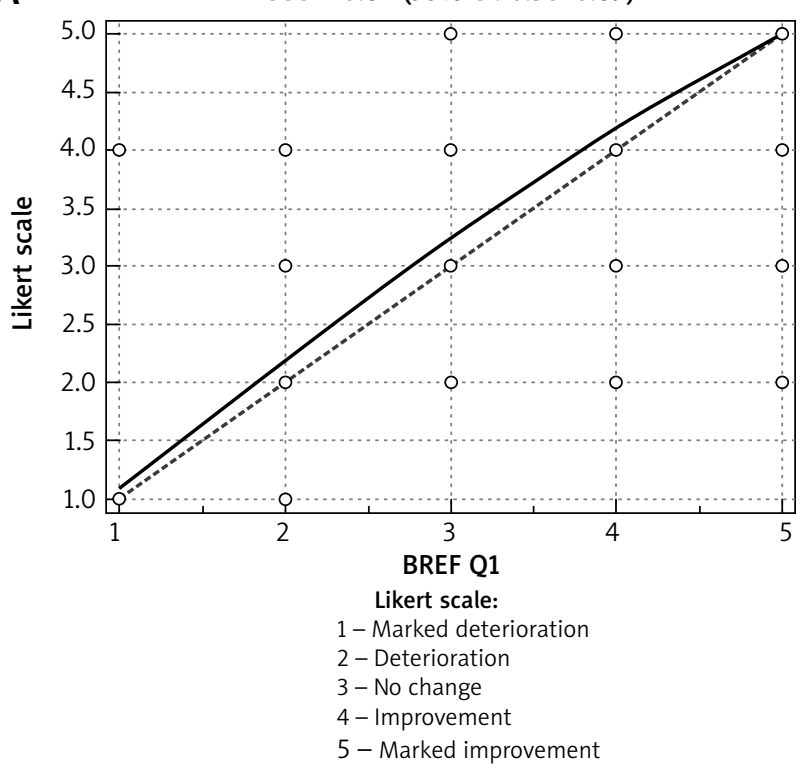

relation coefficient (CCC) was used to evaluate betweenmethod agreement. A $p$-value $<0.05$ was considered significant.

\section{Results}

The study group consisted of 482 patients (391 men, $81 \%)$ aged $58 \pm 9$ years. Their baseline characteristics are depicted in Table I.

Compared with the preoperative period, QoL improved in $75.7 \%$ of patients and only $5.8 \%$ of subjects reported its deterioration (Fig. 2). The overall result in the BREF was $15 \pm 3$ points. The answers in Q1 and Q2 were as follows: $3.89 \pm 0.83$ points and $3.59 \pm 0.79$ points, respectively. In domain ' 5 ' of the BREF the reported level of QoL was $15 \pm 3$ points. For particular domains of the QoL the best results were obtained for psychological health $(15.7 \pm 2.70$ points $)$ and social relationships (14.98 \pm 2.77 points) followed by the environment domain (14.67 \pm 2.46 points) and physical health (14.21 \pm 2.81 points).

There was good agreement between the 5-step Likert scale and the 5-step Q1 ('overall quality of life') and Q2 ('general health') in BREF with a concordance correlation coefficient of CCC $=0.64(95 \% \mathrm{Cl}: 0.58-0.69)$ and $\mathrm{CCC}=$ 0.49 (95\% Cl: 0.43-0.55), respectively (Fig. 3). There was also a statistically significant correlation $(R=0.45-0.62$, $p<0.05)$ between answers on the Likert scale and all domains of QoL in BREF (Fig. 4).

\section{Discussion}

Reductions in angina symptoms and in the rate of major adverse cardiac and cerebrovascular events (MACCE) are major benefits achieved by patients after EACAB [11-14]. At the same time, QoL is an important parameter of treatment effectiveness [15]. Reliable and precise assessment of
B

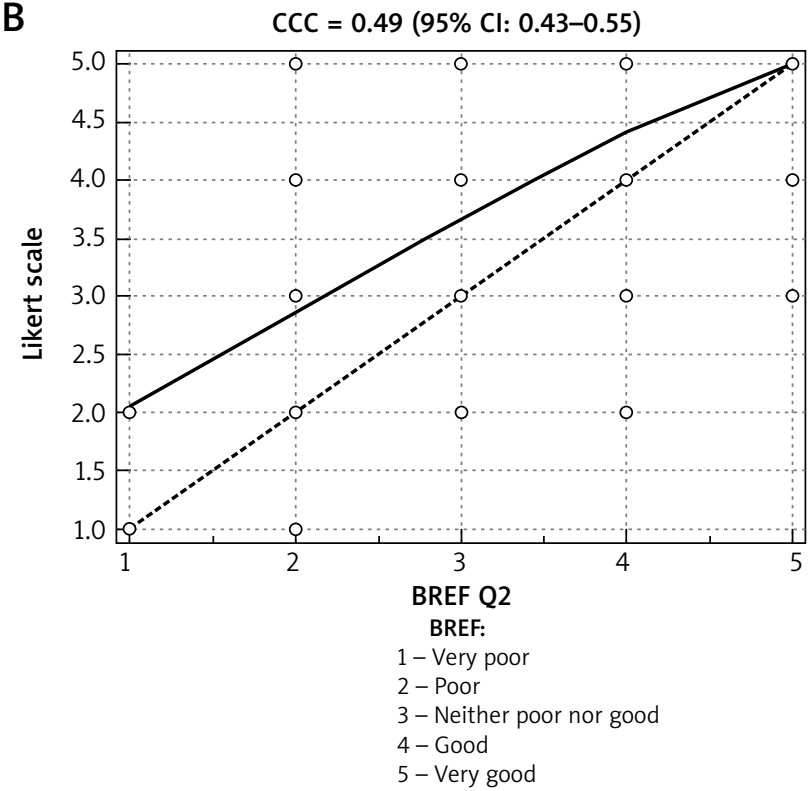

Fig. 3. Agreement between Likert scale and BREF Q1 ('overall quality of life') (A) and Q2 ('general health') (B) 
A

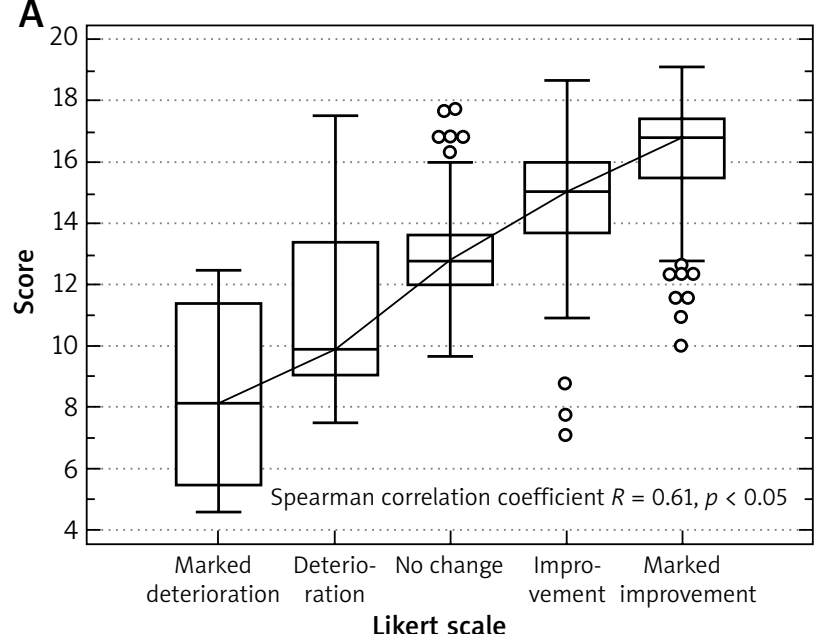

C

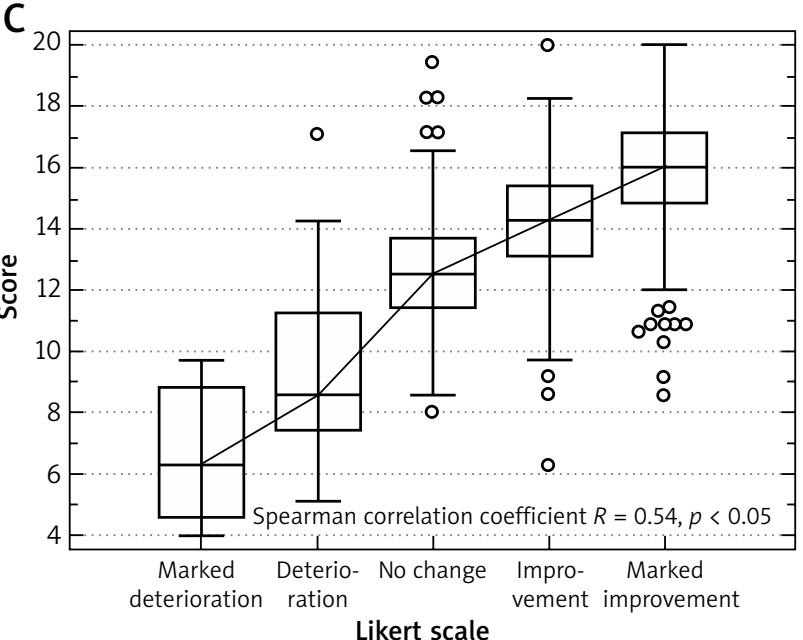

$\mathrm{E}$

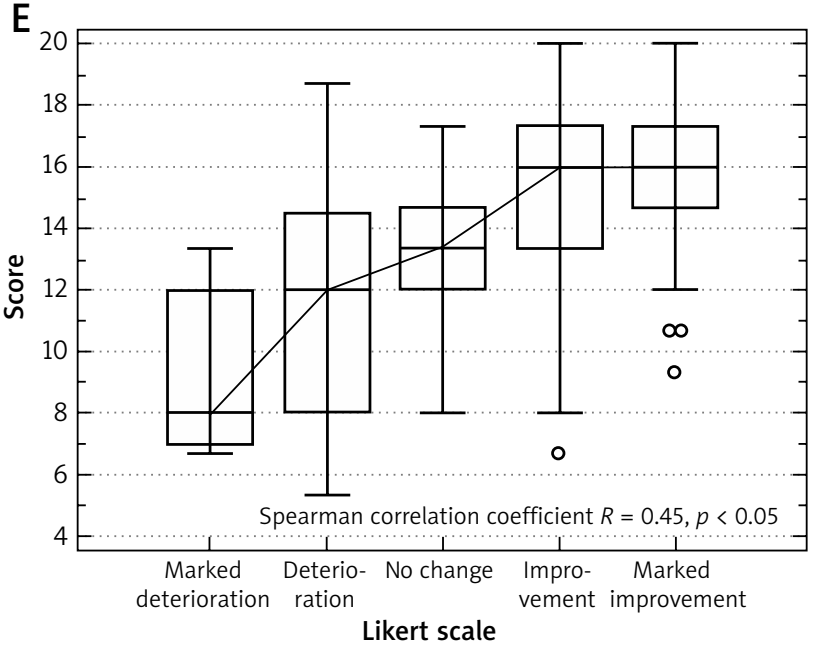

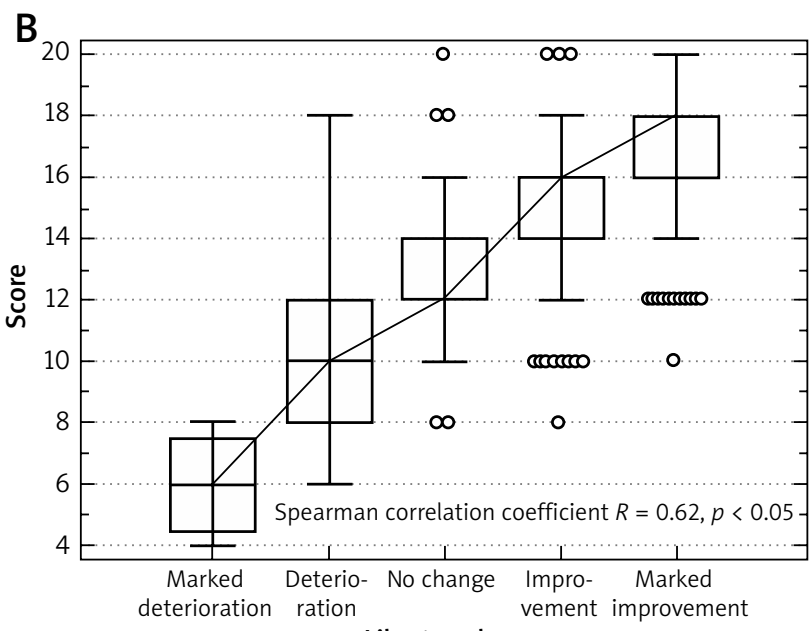

Likert scale

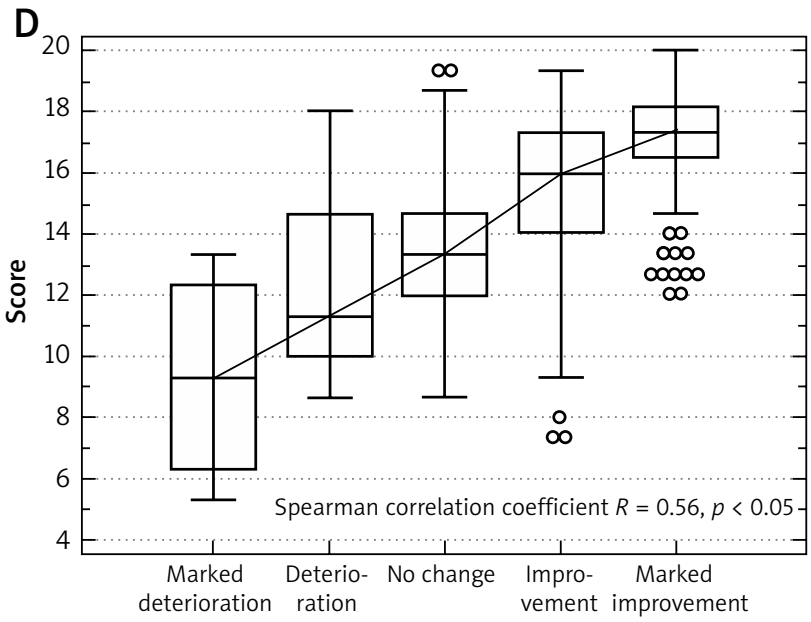

Likert scale

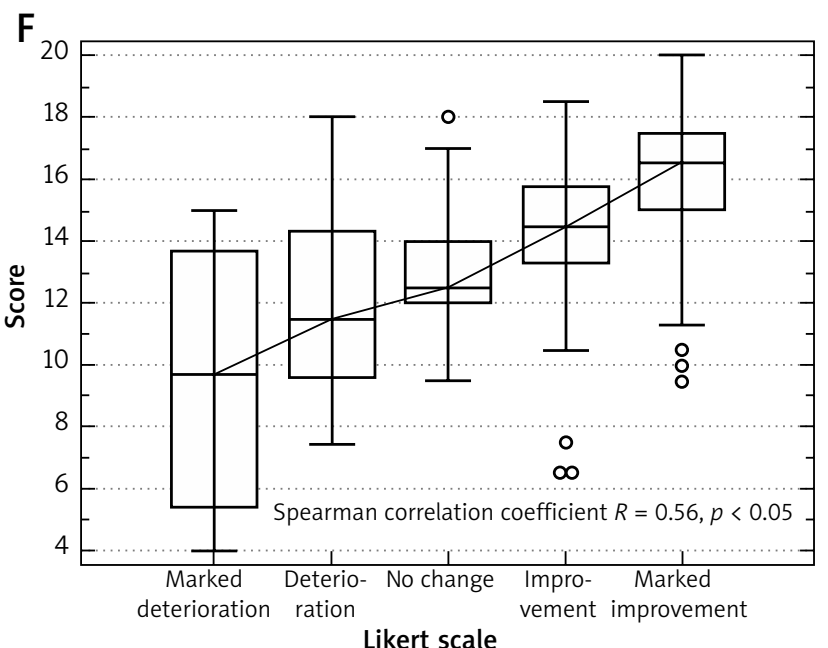

Fig. 4. BREF results by five levels of Likert scale: total score (A), self-assessment of QoL (B), physical health (C), psychological health (D), social relationships $(\mathbf{E})$, environment $(\mathbf{F})$

QoL has become an important goal of clinical decisions for health practitioners. Among patients with ischemic heart disease it is not an easy task as it involves a whole spectrum of variables which are related to the chronicity of the disease process, its progression in time, possible exacerbations of symptoms and various external confounders.
While it is recognized that QoL is ultimately as important as quantity of life, efforts to implement quality of life measurement often fail due to definitional differences, where different investigators attribute different meaning to the term and, as a result, measure different endpoints; and due to insufficient information about available measures, it 
leads to improper test selection and unnecessary regeneration of new items [16].

To our knowledge, our study is the first one confirming that simple assessment of QoL with a 5-step Likert scale may be almost as reliable as complex evaluation with the BREF questionnaire in coronary patients after surgical revascularization. The vast majority of published studies investigating QoL in coronary subjects relied on questionnaires. However, simple tools of subjective assessment have also been applied [17-19]. In the cardiac surgery setting, Markou and Noyez [17] concluded that the visual analogue scale (VAS) helps to identify patients with a good QoL. However, subjects scheduled for high-risk surgery and those with a better quality of life as the primary indication required more extended assessment. Safley et al. [18] successfully implemented in their study the EQ5D VAS to investigate quality of life benefits of percutaneous coronary intervention. Finally, in a prospective observation, Westin and colleagues [19] using a simple tool evaluated betweengender differences in QoL in patients after acute myocardial infarction, coronary artery bypass grafting and $\mathrm{PCl}$.

Firstly, the study population was heterogeneous in terms of the time of observation, which was from several months to 12 years. As a result, QoL in patients shortly after the surgery was dependent on different issues (pain and immobility associated with surgery) than after a few years of follow-up (MACCE occurrence). However, our sub-analyses showed that follow-up duration had an insignificant effect on the answers. Secondly, the complete follow-up data were obtained from $70 \%$ of subjects. Despite this drawback, our study group is currently the largest published cohort of EACAB patients among whom QoL was reported. Thirdly, QoL was assessed only after the procedure and no pre-operative QoL data were available. Similar methodology was, however, used in the several previously published reports [15, 20, 21]. Finally, VAS was found to be less vulnerable to bias from confounding factors than the Likert scale [22]. Because the time needed to complete the VAS is shorter than that to complete the Likert-scale tool, the subjects are less disrupted and focus more on the issue being investigated. But it also means that more complex questionnaires are at higher risk of bias than a Likert scale. Additionally, administration of a Likert scale results in fewer missing values compared to other tools [23].

\section{Conclusions}

The Likert scale is useful in QoL assessment in patients after minimally invasive coronary surgery. This simple and easy-to-use screening method may be used interchangeably with more reliable but also more complex questionnaire tools.

\section{Disclosure}

Authors report no conflict of interest.

\section{References}

1. Schipper H, Clinch JJ, Olweny CHLM. Quality of life studies: definitions and conceptual issues. In: Quality of Life and Pharmacoeconomics in Clinical Trials. $2^{\text {nd }}$ ed. Spilder B (ed.). Lippincott - Raven Publishers Philadelphia 1996; 11-23.
2. Rumsfeld JS, Magid DJ, Plomondon ME, Sacks J, Henderson W, Hlatky M, Sethi G, Morrison DA. Health-related quality of life after percutaneous coronary intervention versus coronary bypass surgery in high-risk patients with medically refractory ischemia. J Am Coll Cardiol 2003; 41: 1732-1738.

3. Cohen DJ, Van Hout B, Serruys PW, Mohr FW, Macaya C, den Heijer P, Vrakking MM, Wang K, Mahoney EM, Audi S, Leadley K, Dawkins KD, Kappetein AP; Synergy between PCI with Taxus and Cardiac Surgery Investigators. Quality of life after $\mathrm{PCl}$ with drug-eluting stents or coronary - artery bypass surgery. N Engl J Med 2011; 364: 1016-1026.

4. Järvinen $\mathrm{O}$, Hokkanen $\mathrm{M}$, Huhtala $\mathrm{H}$. Quality of life 12 years after on-pump and off-pump coronary artery bypass grafting. Coron Artery Dis 2013; 24: 663-668.

5. Hokkanen M, Järvinen $O$, Huhtala H, Tarkka MR. A 12-year follow-up on the changes in health-related quality of life after coronary artery bypass graft surgery. Eur J Cardiothorac Surg 2014; 45: 329-334.

6. Diegeler A, Walther T, Metz S, Falk V, Krakor R, Autschbach R, Mohr FW. Comparison of MIDCAP versus conventional CABG surgery regarding pain and quality of life. Heart Surg Forum 1999; 2: 290-295.

7. Breuer M, Björn G, Sandhaus T, Ferrari M, Doenst T. Quality of life in patients after LAD revascularization by MIDCAB or by PCI. Circulation 2011; 124: A16772.

8. Abdallah MS, Wang K, Magnuson EA, Spertus JA, Farkouh ME, Fuster V, Cohen DJ; FREEDOM Trial Investigators. Quality of life after PCI vs CABG among patients with diabetes and multivessel coronary artery disease: a randomized clinical trial. JAMA 2013; 310: 1581-1590.

9. Ventegodt S, Merrick J, Andersen NJ. Measurement of quality of life II. From the philosophy of life to science. Sci World J 2003; 3: 962-971.

10. The World Health Organization quality of life BREF. Accessed: 30.10.2016. Available at: http://www.who.int/mental_health/media/en/76.pdf?ua=1.

11. Holzhey DM, Cornely JP, Rastan AJ. Review of a 13-year single-center experience with minimally invasive direct coronary artery bypass as the primary surgical treatment of coronary artery disease. Heart Surg Forum 2012; 15: E61-E68.

12. Abu Samra R. Analysis of the long-term outcomes of minimally invasive coronary artery by-pass grafting. PhD Thesis. Medical University of Silesia, Katowice 2011.

13. Thiele H, Neumann-Schniedewind P, Jacobs S, Boudriot E, Walther T, Mohr FW, Schuler G, Falk V. Randomized comparison of MIDCAB versus sirolimus-eluting stenting in isolated proximal left anterior descending coronary artery stenosis. J Am Coll Cardiol 2009; 53: 2324-2331.

14. Fraund S, Herrmann G, Witzke A, Hedderich J, Lutter G, Brandt M, Böning A, Cremer J. Midterm follow-up after minimally invasive direct coronary artery bypass grafting versus percutaneous coronary intervention techniques. Ann Thorac Surg 2005; 79: 1225-1231.

15. Al-Ruzzeh S, Mazrani W, Wray J, Modine T, Nakamura K, George S, Ilsley C, Amrani $M$. The clinical outcome and quality of life following minimally invasive direct coronary artery bypass surgery. J Card Surg 2004; 19: 12-16.

16. Cella DF, Tulski DS. Measuring quality of life today: methodological aspect. Oncology 1990; 4: 29-38.

17. Markou AL, Noyez L. Will cardiac surgery improve my quality of life? Visual analogue score as a first step in preoperative counseling. Neth Heart J 2007; 15: 51-54.

18. Safley DM, Grantham JA, Hatch J, Jones PG, Spertus JA. Quality of life benefits of percutaneous coronary intervention for chronic occlusions. Catheter Cardiovasc Interv 2014; 84: 629-634.

19. Westin L, Carlsson R, Erhardt L, Cantor-Graae E, McNeil T. Differences in quality of life in men and women with ischemic heart disease: a prospective controlled study. Scand Cardiovasc J 1999; 33: 160-165.

20. Wray J, Al-Ruzzeh S, Mazrani W, Nakamura K, George S, Ilsley C, Amrani M. Quality of life and coping following MIDCAB. Qual Life Res 2004; 13: 915-924.

21. Kramer L, Hirsch O, Schlössler K, Träger S, Baum E, Donner-Banzhoff N. Associations between demographic, disease related, and treatment pathway related variables and health related quality of life in primary care patients with coronary heart disease. Health Qual Life Outcomes 2012; 10: 78.

22. Voutilainen A, Pitkäaho T, Kvist T, Vehviläinen-Julkunen K. How to ask about patient satisfaction? The visual analogue scale is less vulnerable to confounding factors and ceiling effect than a symmetric Likert scale. J Adv Nurs 2016; 72: 946-957.

23. Harland NJ, Dawkin MJ, Martin D. Relative utility of a visual analogue scale vs. a six-point Likert scale in the measurement of global subject outcome in patients with low back pain receiving physiotherapy. Physiotherapy 2015; 101: 50-54. 